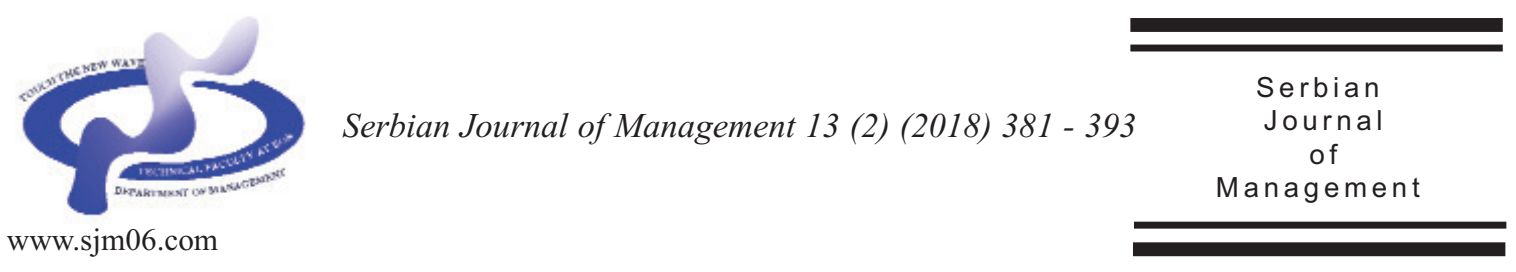

\title{
RELATIONSHIP BETWEEN INFORMATION SHARING AND FLEXIBILITY IN MANAGEMENT OF ENTERPRISES IN AUTOMOTIVE INDUSTRY: AN EMPIRICAL STUDY
}

\author{
Lenka Veselovská*, Mária Kožárová and Ján Závadský \\ Matej Bel University, Banská Bystrica, Faculty of Economics, Tajovského 10, 97590 \\ Banská Bystrica, Slovak Republic
}

(Received 16 May 2018; accepted 25 September 2018)

\begin{abstract}
This paper focuses on the topic of relationship between flexibility of supply chain and information sharing among partners with emphasis on their managerial practices. Since nowadays competition increases, enterprises give more importance to their supply chain management. Our paper provides a complex look on the issues of flexibility and information sharing in Slovak automotive industry and their interdependences. The main aim of this study is to identify relationships between shared information and flexible parameters of supply chains in automotive industry. Achieved results provide a current image of how supply chain management is handled in Slovakia's most significant industry. Our findings indicate that there is a significant dependence between types of information shared and different flexibility types.
\end{abstract}

Keywords: supply chain management, flexibility, information sharing, partners, survey

\section{INTRODUCTION}

Ever-increasing costs of transportation, pressure from global competition, production and delivery times and storage requirements are all influencing decisions to manage supply chain with the aim of achieving success. All these issues lead to ever-growing importance of supply chain flexibility (Datta \& Christopher, 2010; Lummus et al., 2005; Lee, 2004; Blakyta et al., 2017). Various authors provide different views of what flexibility of whole supply chain should involve. In this paper, flexibility is considered as the ability of dynamic production system to cope with both the internal and external changes with high competitive competency and high

\footnotetext{
* Corresponding author: lenka.veselovska@umb.sk
}

DOI: $10.5937 /$ sjm13-17474 
economic profitability (Gong, 2008; Sodhi \& Tang, 2012). Based on the work of various authors (Das, 2011; Groote \& Marx, 2013; Gong, 2008) several types of flexibility can be defined which, for the needs of this research, are contract flexibility, volume flexibility, product mix flexibility, delivery flexibility and manufacturing flexibility.

In order to successfully define such measures, information is essential (Shore, 2014). Information sharing among supply chain partners is a key factor in supply chain management and has widely been regarded as necessary tool to coordinate supply chains activities (Chan \& Chan, 2009; Patnayakuni et al., 2014). It is one of the most important topics in supply chain management, but it is not an easy task to perform due to the various challenges. Results of various research studies indicate that information sharing has positive influence on supply chain performance and can significantly affect relationships among supply chain partners (Wu et al., 2013; He et al., 2011; Chen et al., 2014; Hung et al., 2011; Ruel et al., 2015).

In order to overcome supply chain challenges flexibility measures are introduces. However, such strive for flexibility results in increased supply chain dynamics and vulnerability to negative aspects business environment in terms of new types of risks threatening not only an individual enterprise, but whole supply chain (Sukwadi et al., 2013; Voss \& Williams, 2013; Cheung et al., 2009). Sharing of information among supply chain partners has therefore become the essential next step in supply chain development. Information became useful as a tool for supply chains to create for themselves a capability to respond to threats and to communicate with, coordinate with, and even to control partners within supply chains (Ye \& Farley, 2015).
Information sharing can be exploited to obtain a distinct supply chain advantage (Zhu et al., 2015). Moreover, information sharing among partners has been proved to be a prevalent measure used to increase supply chain performance (Baihaqi \& Sohal, 2013; Yee, 2007; Uckelmann et al., 2008).

Missing from the current literature, however, is the knowledge of how these two strategic components, information sharing and flexibility, can be integrated. Datta and Christopher (2010) discovered that 'centralized information structure without widespread distribution of information and coordination is not effective in managing uncertainty of supply chain networks, even with increased frequency of information flow'.

Consequently, it is obvious that both information sharing and flexibility have become important research issues in supply chain management. Although they have been studied extensively and frequently, our understanding of sharing information strategically and appropriately in order to increase flexibility of supply chains remains limited. To fill this research gap, this study aims to provide a better understanding of how various components of each of these two issues can cooperate and what impact their mutual coexistence in supply chains can have on its ability to meet the ever-changing business conditions. Empirical analyses have proven to be a beneficial tool to gain valuable information from a high number of organizations applicable for whole set of enterprises. Therefore, a closer look on a national level of a certain industry can provide valuable information which concerning a high number of enterprises sharing certain characteristics (Luthra et al., 2016; Sluis \& De Giovanni, 2016; Thun \& Hoenig, 2011; Samuel et al., 2011; Groote \& 
Marx, 2013; Christ, 2014; Shin \& Eksioglu, 2015; Youn et al., 2014; Brandenburg, 2016). The purpose of this paper is to find answers to questions formulated above. This paper seeks to explore the nature of relationship between information sharing among partners and flexibility of supply chains. The main aim of this study is to identify relationships between shared information and flexible parameters of supply chains in automotive industry. In order to achieve this aim data collected from the perspective of enterprises operating in automotive industry in Slovak republic were used. The study is based on analysis of factors influencing the relationships among components of supply chain dynamics. Deeper research into these relationships can serve as guidance for scientific discussions about efficiency of flexible supply chains and can transcendent the boundaries of automotive industry with focus on further supply chains development not only on a national level, but on global level through the lens of supply chain flexibility.

\section{METHODOLOGY}

The baseline for our study is empirical research conducted on sample file of 145 enterprises operating in automotive industry. Data was collected during July and
September 2017 via a structured questionnaire. Our research sample file was created as a representative sample of the base file. This file consists of Slovak companies classified by the SK NACE classification as companies producing vehicles and vehicle components. Moreover, other criteria were considered, mainly the size of company. The decisive criterion was set according to the European Standard No. 2003/361/EC.

Research was conducted on a file consisting of all Slovak automotive companies. The companies were addressed by email. A questionnaire was used to collect data. It consisted of 11 questions. The questionnaire was completed by 151 companies. In key companies method of structured interviews with company's representatives was used. Overall research the sample consists of 145 companies since 6 companies stated that they neither create partnerships nor share information with partners in supply chain. More detailed structure is provided in Table 1.

With the use of "SPSS Statistics and information about data base set" the representativeness of the sample according to the size of the manufacturing company was verified. Based on data from the Statistical bureau of the Slovak Republic the data base set can characterized. In 2017 there were totally 284 companies operating in Slovak automotive industry. The majority of

Table 1. Structure of sample file based on the size of company

\begin{tabular}{ccc}
\hline Number of employees & Number of companies & Percentage \\
\hline $0-9$ & 66 & $45.52 \%$ \\
$10-49$ & 21 & $14.48 \%$ \\
$50-249$ & 34 & $23.45 \%$ \\
over 250 & 24 & $16.55 \%$ \\
\hline Total & $\mathbf{1 4 5}$ & $\mathbf{1 0 0 . 0 0 \%}$ \\
\hline
\end{tabular}

Source: Own elaboration 
them were smaller companies. Table 2 provides information about the structure of base file. There were 114 companies with 9 or less employees and 49 companies with less than 50 employees, which in total represents nearly $60 \%$ of all companies operating in Slovak automotive industry $(57.39 \%)$. Our sample file was structured similarly in order to achieve the representativeness of research results. Companies with less than 50 employees represent precisely $60 \%$ of all companies in our sample file. On the other hand, there were 52 companies with more than 250 employees operating on Slovak automotive market at the time of our research $(16.55 \%$ of all automotive companies). Nearly $19 \%$ of our sample file consists of such large companies. The verification of the representativeness of the sample is based on these data.

The majority of companies are mostly small and medium sized companies. Nearly two thirds of them are considered main supplier (62.76\%) and many are also suppliers of main component (26.9\%).

To verify the representativeness of the sample Chi-square test was used. The null hypothesis assumes that the sample is representative. The alternative hypothesis is an assumption of non - representativeness of the sample. From the mathematician point of view the hypothesis are formulated as:
$\mathrm{H}_{0}=\mathrm{F}(\mathrm{x})=\mathrm{G}(\mathrm{x}) ; \mathrm{H}_{1}=\mathrm{F}(\mathrm{x}) \neq \mathrm{G}(\mathrm{x})$.

Statistics testing in SPSS software is based on following formula (1):

$$
X^{2}=\sum_{j=1}^{r} \frac{\left(n_{j}-m_{j}\right)^{2}}{m_{j}} \approx X_{(r-1)}^{2}
$$

where:

$$
\begin{aligned}
& \mathrm{X}^{2} \text { - is Pearson statistics, } \\
& \mathrm{r} \text { - is line, } \\
& \mathrm{n} \text { - is overall frequency in the base set, } \\
& \mathrm{m}-\text { is measured frequency. }
\end{aligned}
$$

Consequently, the critical value of $\chi^{2}$ distribution for ( $r-1)$ degrees of freedom and selected level of significance $\alpha$ from tables of critical values of chi square can be identified. However, Chi square test requires the fulfillment of two conditions:

- No interval should have zero frequency;

A maximum of $20 \%$ confidence intervals should have frequency less than 5 .

The test was performed at a significance level of $95 \%$. If the critical value is lower than value of tested statistics, null hypothesis is rejected and alternative hypothesis $\mathrm{H} 1$ is accepted. Our calculated chi square value was 21.171 ; it means that the null hypothesis can be accepted. Our sample is representative.

Table 2. Structure of base file based on the size of company

\begin{tabular}{ccc}
\hline Number of employees & Number of companies & Percentage \\
\hline $0-9$ & 114 & $40.14 \%$ \\
$10-49$ & 49 & $17.25 \%$ \\
$50-249$ & 69 & $24.30 \%$ \\
over 250 & 52 & $18.31 \%$ \\
\hline Total & $\mathbf{2 8 4}$ & $\mathbf{1 0 0 . 0 0 \%}$ \\
\hline
\end{tabular}

Source: Own elaboration 
Furthermore, Pearson correlation test and Multivariate Regression Analysis were used in order to achieve the main aim of this paper, which is to identify relationships between shared information and flexible parameters of supply chains in automotive industry.

\section{RESULTS AND DISCUSSION}

\subsection{Empirical study results}

Firstly, this research focused on examining the issues of the building partnerships within supply chains and consequently on information sharing with partners. It was discovered that $82.76 \%$ of Slovak automotive companies build joint strategies with key partners within their supply chain. However, in the case of $63.33 \%$ of these companies, joint strategies are based on contracts. Only $36.67 \%$ of these companies base their joint strategies with partners on cooperation. Moreover, they represent less than $30 \%$ of all companies in Slovak automotive industry. The types of information that are most commonly shared among partners and how the information is shared were also examined. Results are provided in Table 3 in form of values of correlation coefficients calculated among elements in two sets. The first set of indicators consists of five types of flexibilities as drafted by literature review. Our research examined these flexibilities types: contract flexibility (CFL), volume flexibility (VFL), product mix flexibility (PFL), delivery flexibility (DFL) and manufacturing flexibility (MFL). The second set of indicators consists of various types of information that partners share among each other. These include research and development (RAD), technological trends (TET), know-how (KNH), direct assistance (DAS), problem solving experiences (PRS), market changes and trends $(\mathrm{MCH})$, marketing experience (MEX), finance (FIN), customer requirements (CRQ) and optimization techniques (OPT). It was discovered that there is a significant positive dependence between contract flexibility and sharing information about customer requirements $(0.781)$. However, the strongest dependence in Slovak automotive industry is between sharing these information and volume flexibility (0.899). This finding indicates that sharing information is a useful tool to flexibly meet customers' requirements in this industry. Moreover, a significant relationship between sharing know-how and both the volume flexibility and manufacturing flexibility was revealed. The potential for improvement lies mainly in the area of delivery flexibility, since there are even some negative correlations among this type of flexibility and some types of shared information. Findings resulting from research and development are clearly not shared enough to generate volume and product mix flexibilities, much less the delivery flexibility. The only significant dependence can be marked in relation with manufacturing flexibility, which is usually the main purpose of sharing this information among partners in automotive industry. Sharing optimizing techniques is also not very common in Slovak automotive industry, which also results in no significant correlating flexibility with the exception of manufacturing flexibility where a medium positive dependence exists. However, this result is not suitable for industry where both optimization and flexibility should be everyday's aims. Furthermore, this issue can be examined from a different point of view. 
Companies were asked to provide data on the nature of information shared. Answers were divided into three categories: products, processes and sources. These findings were examined in relation with flexibility types. These results indicate that sharing information about products has direct impact on volume flexibility and product mix flexibility. Sharing information about processes is significantly correlated with delivery flexibility and manufacturing flexibility. However, sharing information about sources has significant impact only on manufacturing flexibility.

Furthermore, this research looked into forms in which this information is shared. Several options for sharing information were examined. They were technological lectures, conferences, problem-solving visits, temporary employee exchanges, on-site installations, after sale services and business negotiations. Out of those forms, the one that mostly affects flexibility is clearly the latest. Sharing information during business negotiations provides direct effect on all flexibilities. The contract flexibility and delivery flexibility have even a strong dependence with this form of information sharing among partners in supply chains. Conferences, technological lectures and temporary employee exchanges are not among commonly used forms of sharing information and consequently have no direct impact on any flexibility types. Problemsolving visits are not common among partners in Slovak automotive industry, however there is potential for future development, especially in relation with manufacturing flexibility. An interesting finding is significant negative dependence between after sale services and contract flexibility (-0.398).

Moreover, the results revealed that only $16.55 \%$ of companies have at least one back up supplier ready for case when main supplier - partner fails to provide desirable amount of raw material or components or partner fails to deliver them on time. This result indicates lower levels of flexibility of their supply chains since having various suppliers ready is one of the basic tools to increase flexibility. However, this result could indicate higher rate of cooperation between partners in supply chain. Based on this assumption it is possible to look further into this issue using correlation between

Table 3. Dependences among flexibility types and types of information shared

\begin{tabular}{cccccc}
\hline Correlation coefficient & CFL & VFL & PFL & DFL & MFL \\
\hline RAD & 0.091 & 0.307 & 0.325 & -0.009 & 0.697 \\
TET & -0.144 & 0.276 & 0.322 & 0.091 & 0.498 \\
KNH & 0.205 & 0.701 & 0.520 & 0.113 & 0.721 \\
DAS & 0.228 & 0.233 & 0.241 & 0.196 & 0.455 \\
PRS & 0.366 & 0.348 & 0.355 & 0.198 & 0.302 \\
MCH & 0.348 & 0.296 & 0.206 & -0.103 & 0.008 \\
MEX & 0.401 & 0.201 & 0.077 & -0.006 & 0.129 \\
FIN & 0.417 & 0.395 & 0.349 & 0.338 & 0.402 \\
CRQ & 0.781 & 0.899 & 0.566 & 0.050 & 0.542 \\
OPT & 0.006 & -0.014 & 0.028 & -0.163 & 0.317 \\
\hline
\end{tabular}

Source: Own elaboration 
these results and level of trust among partners in supply chain.

According to the data an assessment of the quantitative measure of some type of correlation and dependence between having a back up supplier ready and various aspects of flexibility was conducted which revealed that there is medium positive correlation between preparing for contingences and contract flexibility. This result indicates that even though this flexibility is a significant issue for companies that pay attention to this matter, not many companies in Slovak automotive industry yet focus on achieving flexibility by having a back up supplier ready. This finding can be explained by significant negative dependence between preparing for contingences and trust among partners. Moreover, it was discovered that there is a medium direct dependence between delivery flexibility and preparing for contingences in Slovak automotive industry. This finding is rather surprising since these aspects should be closely related. Slovak automotive industry does not pay enough attention to issue of flexibility. Most partnerships are still based mainly on signed contracts and changes have to be discussed by all parties involved. Over two thirds of companies stated this fact as their common operational practice $(69.66 \%)$.

The concept of supply chain flexibility was further studied in relation with various aspects identified as essential for successful partnerships as a premise of information sharing. Table 4 provides the values of correlation coefficients between types of flexibility and key partnership prerequisite. This research examined whether there is dependence between flexibility and some of the key aspects of partnership such as trust (TRS), honesty (HNS), reliability (RLB) and commitment (CMT).

Data provided indicates that contact flexibility is directly dependent on both trust and reliability. However, manufacturing, volume and product mix flexibilities are not significantly influenced by any partnership aspects. Delivery flexibility shows a strong direct dependence with reliability of partner. The relationship between this flexibility type and trust is also significant. The potential for future development is clear based on these results, however nowadays these results indicate that the key partnership prerequisites have no impact on flexibility in Slovak automotive supply chains.

Discovered relationships among flexibility types and types of information shared are considered key findings. Therefore, a simple model of dependences was created (Figure 1). This figure illustrates the most significant relationships discovered in this study. The most obvious fact is that delivery flexibility does not have any significant dependence with any of information shared types. The factor of customer requirements shares significant dependences with four flexibility types, which is the most of all. The factor of know-

Table 4. Dependences among significant partnership issues and flexibility types

\begin{tabular}{cccccc}
\hline Correlation coefficient & CFL & VFL & PFL & DFL & MFL \\
\hline TRS & 0.311 & 0.054 & -0.032 & 0.402 & -0.168 \\
HNS & 0.226 & -0.085 & -0.125 & 0.173 & 0.067 \\
RLB & 0.690 & 0.105 & 0.095 & 0.712 & -0.075 \\
CMT & 0.133 & 0.080 & 0.007 & 0.125 & 0.034 \\
\hline
\end{tabular}

Source: Own elaboration 


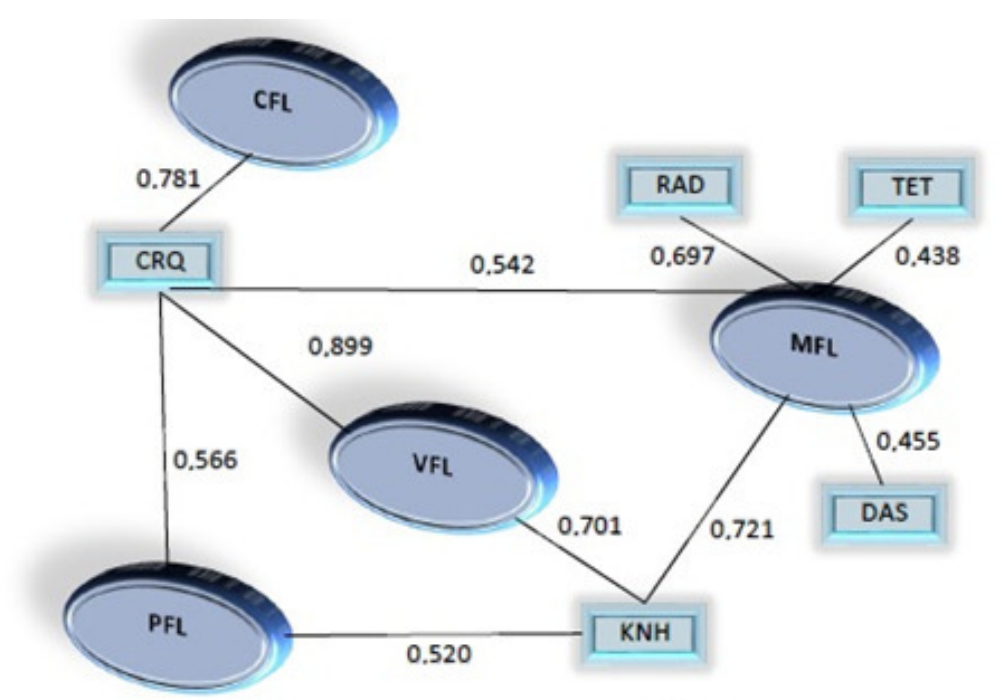

Figure 1. Model of dependences among flexibility types and types of information shared

how relates with all flexibility types with the exception of contract flexibility and delivery flexibility. Moreover, manufacturing flexibility shares the highest number of significant relationships with selected types of information shared.

\subsection{Discussion}

In order to further explore the relationships between shared information and flexible parameters of supply chains in automotive industry and to achieve statistically valuable results multivariate regression model was formulated and tested. Firstly, our assumption was that there is a direct positive correlation between level of flexibility and type of information shared. Results indicate that the levels of correlation are not significant enough to confirm this assumption. However, the exceptions were three types of information shared which are significantly correlated with enterprise's level of flexibility. They are research and development, know-how and customer requirements. The second assumption stated there is a direct positive correlation between level of flexibility and category of information shared. These categories are product, process and sources. This assumption was not confirmed. Thirdly, existence direct positive correlation between level of flexibility and form of information sharing was examined. With the exception of business negotiations these correlations are insignificant. This research also examined the nature of relationship between level of flexibility and position of enterprise in its supply chain. Assumption was that this relationship is significantly correlated. Our results indicate that there is a significant correlation between these factors. Therefore, it can be concluded that position of enterprise in its supply chain significantly affects the levels of flexibility. Similar results were obtained by Choi \& Hartley (1996), however, the main focus of their study was not just on flexibility, but also on other supply chain quality aspects such as price and reliability in order to ascertain the best supplier selection practices. Furthermore, Mishra et al. (2017) discovered the importance of relationship between flexibility and position in supply chain. Their 
focus was only on manufacturing flexibility; therefore, the opportunity to draw comparisons is limited to this one type of supply chain flexibility, whereas in our study the focus was on various other flexibility types. On the other hand Manders et al. (2016) found no connection between flexibility and organization's positions in the supply chain. They concluded that there is no support for overall supply chain flexibility based on its individual aspects. These results provide a valuable source for comparisons in terms of supply chain flexibility and position in supply chain, however there are limitations since their study was conducted on a significantly different sample file. The main focus was on enterprises operating in food industry with emphasis on those organizations that provide transportation services.

There was also assumed that size of enterprise has an impact on level of supply chain flexibility. This assumption was proven correct. It was discovered that bigger enterprises perceive their supply chains as more flexible. Our conclusion is that higher levels of supply chain flexibility are more likely achieved by bigger enterprises. The last assumption focused on relationship between level of supply flexibility and extant of information shared. Our results indicate that there is a significant dependence. Our conclusion is that enterprises in more flexible supply chains are associated with higher extant of enterprise's willingness to share information.

The idea of developing supply chain flexibility through increasing the quality of relationships among its partners is not a novel concept. There are several studies which provided valuable evidence to the importance of this issue (Kim et al., 2010; Song et al., 2008; Rezaei et al., 2015; Chan
\& Chan, 2009). However, this concept has not yet been fully developed in compliance with ever-increasing global competition and in regard with customer requirements which change often and rapidly. Therefore, the need to design supply chains as agile systems could be the answer to this need. Building partnerships among key members of supply chains and sharing information them can become a useful tool to help increase this much needed flexibility and consequently to improve the performance of entire supply chains. However, our results proved that only certain specific aspects of information sharing among partners help achieve flexibility of whole supply chain. They are mainly the factor of reliability of partner which affects both the contract and delivery flexibility in supply chain. The majority of information concerning business activities throughout the supply chain is shared only during business negotiations. A significant potential for improvement lies in this area of supply chain management. Enterprises should also focus on the character of information shared with partners in supply chains. Information concerning customer requirements, know-how and research and development can all significantly affect supply chain flexibility, specifically volume, contract and manufacturing flexibilities.

\section{CONCLUSION}

The main purpose of our research was to identify correlation relationships between shared information and flexible parameters of supply chains in automotive industry. In order to achieve this goal data provided by Slovak companies operating in automotive industry was used via survey. Our paper provides the overview of how various types 
of flexibility correlate with sharing information. The parameters examined describe not only the current state in Slovak automotive industry, but also provide areas where improvement can be essential in order to achieve desirable results by companies involved. These findings provide valuable guidelines for managers in practice since they reveal potential threats to supply chain performance and opportunities to further increase the resilience of their supply chain by creating partnerships through critical forms of information sharing. Appling measures targeting the volume and contract flexibility can also help increase company's ability to meet customers' requirements. Nowadays, reliability is the most important characteristic of desirable supply chain partner. It is even more important and has more impact on joint flexibility than other characteristics such as honesty, trust and commitment. Learning from the best possible benchmarks can assist managers to gain competitive advantage in current rapidly changing conditions on global markets which is nowadays proving essential for survival of Slovak automotive companies, especially under the pressure of Asian manufacturing companies.

This paper contributes to current research field of business enterprises and management science by providing an overview of how managers in practice can locate an interesting source of competitive opportunity by analyzing their supply chains. The relationship between partners is the key factor of success of whole supply chain and consequently the quality of information they assist among each other is the foundation of achieving an agile and responsive supply chain especially in highly competitive industry such as the automotive industry. Furthermore, the results presented in this research study serve as an interesting starting point for researchers interested in supply chain flexibility and information sharing within supply chain. This paper can assist in future development of this research topic and provide foundation for further research into connections of these two significant issues in supply chain management. Therefore, this topic is an appropriate area to research as companies nowadays strive to improve supply chain performance by revising existing industry practices. However, the main limitation of this research was the complexity of this issue. Many ideas for further research studies can be found in focusing on some of the particular problems stated above, which can be further examined in more detailed in order to provide more accurate guidelines for managers in practice in terms of forms and types of information sharing thorough the supply chain. The study of particular measures applied to achieve flexibility was omitted, even though it might be interesting to examine how some measures other that information sharing can affect supply chain flexibility. This paper provides a complex look on this issue within Slovak automotive industry using a representative sample of companies.

\section{References}

Baihaqi, I., \& Sohal, A.S. (2013). The impact of information sharing in supply chains on organisational performance: an empirical study. Production Planning \& Control: The Management of Operations, 24 (8-9), 743-758.

Blakyta, G., Matusova, O., Lanovska, H., \& Adamenko, V. (2017). Integral assessment of business environment security. Problems and perspectives in management, 15 (4), 


\title{
ОДНОС ИЗМЕТУ РАЗМЕНЕ ИНФОРМАЦИЈА И ФЛЕКСИБИЛНОСТИ УПРАВЉАҢУ ПРЕДУЗЕЋЕМ У АУТОМОБИЛСКОЈ ИНДУСТРИЈИ: ЕМПИРИЈСКА АНАЛИЗА
}

\author{
Lenka Veselovská*, Mária Kožárová, Ján Závadský
}

\section{Извод}

Овај рад се фокусира на односе између флексибилности ланца снабдевања и размене информација међу партнерима, са нагласком на њихову менаџмент праксу. С обзиром да се конкуренција данас повећава, предузећа придају већи значај управљању ланцем снабдевања. Рад приказује сложено питање флексибилности и размене информација у словачкој аутомобилској индустрији и њихову међузависност. Главни циљ ове студије је идентификација повезаности између размене информација и флексибилности ланаца снабдевања у аутомобилској индустрији. Добијени резултати дају тренутну слику о томе како се руководи менаџментом ланца снабдевања у најзначајнијој индустрији у Словачкој. Резултати показују да постоји значајна зависност између типова информација које се деле и различитих типова флексибилности.

Кључне речи: управљање ланцем снабдевања. флексибилност, дељење информација, партнери, преглед

280-292.

Brandenburg, M. (2016). Supply chain efficiency, value creation and the economic crisis - An empirical assessment of the European automotive industry 2002-2010. International Journal of Production Economics, 171, 321-335.

Chan, H.K., \& Chan, F.T.S. (2009). Effect of information sharing in supply chains with flexibility. International Journal of Production Research, 47 (1), 213-232.

Chen, J.V., Wang, C.L., \& Yen, D.C. (2014). A causal model for supply chain partner's commitment. Production Planning \& Control: The Management of Operations, 25 (9), 800-813.

Cheung, D.K.K., Welford, R.J., \& Hills, P.R. (2009). CSR and the environment: business supply chain partnerships in Hong Kong and PRDR, China. Corporate Social Responsibility and Environmental
Management, 16 (5), 250-263.

Choi, T.Y., \& Hartley, J.L. (1996). An exploration of supplier selection practices across the supply chain. Journal of Operations Management, 14 (4), 333-343.

Christ, K.L. (2014). Water management accounting and the wine supply chain: Empirical evidence from Australia. The British Accounting Review, 46 (4), 379-396.

Das, K. (2011). Integrating effective flexibility measures into a strategic supply chain planning model. European Journal of Operational Research, 211 (1), 170-183.

Datta, P.P., \& Christopher, M.G. (2010). Information sharing and coordination mechanisms for managing uncertainty in supply chains: a simulation study. International Journal of Production Research, 49 (3), 765-803.

Gong, Z. (2008). An economic evaluation model of supply chain flexibility. European 
Journal of Operational Research, 184 (2), 745-758.

Groote, S.E., \& Marx, T.G. (2013). The impact of IT on supply chain agility and firm performance: An empirical investigation. International Journal of Information Management, 33 (6), 909-916.

He, Q., Gallear, D., \& Ghobadian, A. (2011). Knowledge transfer: The facilitating attributes in supply-chain partnerships. Information Systems Management, 28 (1), 57-70.

Hung, W.H., Ho, C.F., Jou, J.J., \& Tai, Y.M. (2011). Sharing information strategically in a supply chain: antecedents, content and impact. International Journal of Logistics Research and Applications, 14 (2), 111-133.

Kim, D.Y., Kumar, V., \& Kumar, U. (2010). Performance assessment framework for supply chain partnership. Supply Chain Management: An International Journal, 15 (3), 187-195.

Lee, H.L. (2004). Triple A-supply chain. Harvard business review, 82 (10), 102-112.

Lummus, R.R., Vokurka, R.J., \& Duclos, L.K. (2005). Delphi study on supply chain flexibility. International Journal of Production Research, 43 (13), 2687-2708.

Luthra, S., Garg, D., \& Haleem, A. (2016). The impacts of critical success factors for implementing green supply chain management towards sustainability: an empirical investigation of Indian automobile industry. Journal of Cleaner Production, 121, 142-158.

Manders, J.H.M., Caniëls, M.C.J., \& Ghijsen, P.W.T. (2016). Exploring supply chain flexibility in a FMCG food supply chain. Journal of Purchasing and Supply Management, 22 (3), 181-195.

Mishra, D., Sharma R.R.K., Gunasekaran, A., Papadopoulos T., \& Dubey, R. (2017).
Role of decoupling point in examining manufacturing flexibility: an empirical study for different business strategies. Total Quality Management and Business Excellence, Retrieved March 17, 2018, from https://www.tandfonline.com/doi/full/10.108 0/14783363.2017.1359527

Patnayakuni, R., Rai, A., \& Seth, N. (2014). Relational antecedents of information flow integration for supply chain coordination. Journal of Management Information Systems, 23 (1), 13-49.

Rezaei, J., Ortt, R. \& Trott, P. (2015). How SMEs can benefit from supply chain partnerships. International Journal of Production Research, 53 (5), 1527-1543.

Ruel, S., Samuel, K.E. \& Vignard, N. (2015). Collaboration and information sharing in an internal supply chain during an innovation project. Supply Chain Forum: An International Journal, 14 (4), 32-41.

Samuel, K.E., Goury, M.-L., Gunasekaran, A., \& Spalanzani, A. (2011). Knowledge management in supply chain: An empirical study from France. The Journal of Strategic Information Systems, 20 (3), 283306.

Shin, S., \& Eksioglu, B. (2015). An empirical study of RFID productivity in the U.S. retail supply chain. International Journal of Production Economics, 163, 8996.

Shore, B. (2014). Information sharing in global supply chain systems. Journal of Global Information Technology Management, 4 (3), 27-50.

Sluis, S., \& De Giovanni, P. (2016). The selection of contracts in supply chains: An empirical analysis. Journal of Operations Management, 41, 1-11.

Sodhi, M.S., \& Tang, C. S. (2012). Strategic approaches for mitigating supply chain risks. International Series in 
Operations Research \& Management Science, 172, 95-108.

Song, H., Yu, K., \& Chatterjee, S.R. (2008). An empirical examination of access flexibility fit, trust and performance between supplier and distributor. International Conference on Wireless Communications, Networking and Mobile Computing, WiCOM 2008, Dalian, China.

Sukwadi, R., Wee, H.M., \& Yang, C.C. (2013). Supply chain performance based on the lean-agile operations and supplier-firm partnership: An empirical study on the garment industry in Indonesia. Journal of Small Business Management, 51, 297-311.

Thun, J.H., \& Hoenig, D. (2011). An empirical analysis of supply chain risk management in the German automotive industry. International Journal of Production Economics, 131 (1), 242-249.

Uckelmann, D., Hamann, T., \& Zschintzsch, M. (2008). Performance increase and benefit compensation in supply chains by partial information sharing and billing based on identification of returnable transport items. International Journal of RF Technologies: Research and Applications, 1 (1), 23-43.

Voss, M.D., \& Williams. Z. (2013). Public-private partnerships and supply chain security: C-TPAT as an indicator of relational security. Journal of Business Logistics, 34 (4), 320-334.

Wu, M.Y., Chou, H.P., Shih, Y.Y., \& Wang, J.H. (2013). Supply chain performance improvement through partner relationship management in the high tech industry. International Journal of Management Science and Engineering Management, 6 (3), 210-218.

Ye, N., \& Farley, T. (2015). Information sharing and control in homogenous and heterogeneous supply networks under different market conditions. International Journal of Modelling and Simulation, 26 (2), 160-168.

Yee, S.T. (2007). Impact analysis of customized demand information sharing on supply chain performance. International Journal of Production Research, 43 (16), 3353-3373.

Youn, S.H., Yang, M.G., Kim, J.H., \& Hong, P. (2014). Supply chain information capabilities and performance outcomes: An empirical study of Korean steel suppliers. International Journal of Information Management, 34 (3), 369-380.

Zhu, D.S., Lee, Z.C., Ho, C.T., Hong, C.H., \& Lin, Y.J. (2015). Will you share? A study of motives and consequences of supply chain partners' information integration. Supply Chain Forum: An International Journal, 15, 4-18. 